\title{
Dogmatische aspecten van het voortbestaan van de Christelijke Gereformeerde Kerk in 1892 - Enkele notities
}

W. van 't Spijker

Dept. Kerkgeschiedenis en Kerkrecht

Theologische Universiteit van de Christelijke Gereformeerde Kerken APELDOORN

Nederland

\begin{abstract}
Two doctrinal points of difference can basically be linked to people of the ('hristian reformed conviction who did not take part in the Unification of 1892: an ecclesiological and a soteriological point of view. Both aspects are closely related to the spiritmality of these seceders.

Kuyper's conception of the church was based on a tight relarionship between election and church; he made a distinction between the church as an institute and the church as an organism at the same time emphasising her pluriformity within a broad socio-cultural context. Exactly at this point his views clashed with the conception of the seceders. The seceders wished to remain true to the classic confession, maintaining the concept of the church as formulated in article 36 of the Belgic Confession. Their starting point w'as the reality of the covenant, and they esteemed the church as an institute more highly than Kuyper did.

lispecially Van Lingen raised objections to Kuyper's teachings on assumed regeneration. In contra-distinction to Kuyper the seceders wished to draw attention to the subjective side of soteriology: salvation is not only to be preached, but it also has to be believed. Faith does not suppose God's grace, but it underlies the truth of His promise.

The appeal by the seceders to the principle of the Secession was legitimate. It was not only a doctrinal difference: reformed spirituality was in danger. and according to the reformed point of view, reformed spirinality is noursshed by the church.
\end{abstract}




\section{Inleiding}

\subsection{Bezwaren tegen de Vereniging}

De geschiedenis van de Vereniging tussen de Nederduitsche Gereformeerde Kerken en de Christelijke Gereformeerde Kerk, die tot stand kwam op 17 juni 1892, is herhaaldelijk beschreven (Bouma, 1967; Kok, 1939). Op dit moment liggen er als een voorproefje van de komende herdenking in deze zomer twee publikaties waarin aandacht aan de Vereniging wordt gewijd (Endedijk, 1990:7389; Schram, 1992). Een klein aantal gemeenten en een even gering getal predikanten weigerde de stap mee te maken. Zij hadden op de synode van de Christelijke Gerefonneerde Kerk nog voordat deze tot de Vereniging besloot een bezwaarschrift ingediend, bestaande uit vijf punten (Handelingen, 1988:X,13-18). Deze raakten achtereenvolgens het feit dat vóór deze Vereniging de gemeenten zelf er buiten waren gelaten: de manslidmaten waren niet bijeengeroepen om al of niet in te stemmen met de gang van zaken. De rechten van de gemeente waren daardoor wezenlijk aangetast.

In de tweede plaats werd gewezen op de tegenstrijdige beginselen die in de Afscheiding en de Doleantie aan het licht waren getreden.

Het derde bezwaar raakte de methode van de Doleantie, die voetstoots leden uit de Hervormde Kerk accepteerde zonder dat een degelijk onderzoek was ingesteld. Men achtte dit in strijd met het principe van de kerkelijke tucht.

Het vierde bezwaar stond in verband met het feit dat de gemeenten ter plaatse elkaar niet kenden, en dat de wederkerige liefde ontbrak.

Aan het laatste bezwaar werd veel gewicht toegekend:

En eindelijk is het ons een overwegend bezwaar voor gereformeerd te erkennen, wat door voorgangeren der doleerende kerken in den laatsten tijd in het publiek is uitgesproken en geleerd omtrent de Wedergeboorte en den Heiligen Doop. Wij achten het overbodig dit nader te ontwikkelen. Om zelfs den schijn te vermijden, dat het ons om personen te treffen te doen zou zijn, noemen wij geene namen. Er is in 't publiek genoeg over geschreven, dat u niet onbekend kan zijn (Handelingen, 1988:17).

Het bezwaarschrift werd op de synode te Amsterdam besproken, maar de bezwaren werden niet overgenomen. Zij werden afgewezen. Wat de bijeenroeping van de gemeenten betreft: in dit verband werd door een pre-adviseur verwezen naar de independenten, terwijl in de gereformeerde kerkregering de kerkeraad beslissingen nam. Het verschil tussen het beginsel van de Afscheiding en dat van de Doleantie bood geen grond voor de gedachte dat er een eindeloze 
verwarring op de Vereniging zou volgen. Wat de methode van reformatie betreft die in de Doleantie werd toegepast: men zou deze niet ongedaan kunnen maken. Het ontbreken van de wederzijdse liefde werd betwist. En het verschil inzake wedergeboorte en doop zou ter sprake kumnen worden gebracht op bevoegde kerkelijke vergaderingen (Handelingen, 1988:X,17). Het argument van de synode met betrekking tot de aangegeven bezwaren luidde bij wijze van samenvatting, "wijl men geene kerkelijke vereeniging mag weigeren om redenen, waarom men eene kerkelijke vereeniging niet zou mogen verbreken" (Handelingen, 1988: $\mathrm{X}, 18)$.

\subsection{Reactie tegen het optreden van Kuyper}

Wij willen in deze bijdrage niet uitvoerig ingaan op de geschiedenis van de Vereniging, en evenmin op de gebeurtenissen die geleid hebben tot het voortbestaan van de Christelijke Gereformeerde Kerk (Drayer \& Van 't Spijker, 1984: 121-148; Van 't Spijker, 1982:9-27). De reactie tegen het optreden van Kuyper werd voor een belangrijk deel geleid door de redactie van Het Stichtsche Wekkerlje, later Het Wekkertje sinds 1892. Hoofdredacteur was jaren aaneen ds J. Wisse Czn (1843-1921). Hij was predikant van de Christelijke Gereformeerde Kerk in 's-Gravenhage, had in Kampen gestudeerd en voonamelijk gemeenten gediend die afkonstig waren uit de kringen van de z.g. Kruisgezinden. Deze kenmerkten zich door een spiritualiteit die haar voonaamste voedingsbron vond in de lectuur van de Nadere Reformatie (Van 't Spijker, 1984a:168-173). In ds. Wisse herkennen we een christelijk-gereformeerd predikant die zich geheel met de gedachtenwereld van de Afscheiding verbonden wist.

Naast hem stond in zijn verzet tegen Kuyper de oprichter van het eerste christelijke gymnasium in Nederland, ds. F.P.L.C. van Lingen (1832-1913). Van Lingen was een studievriend van A. Kuyper (Ruiter, 1965:13 e.v.). Hij had evenals deze een ingrijpende bekering doorgemaakt. Van Lingen had zich op het herstel van de kerk gericht door zijn pedagogisch talent in dienst van de reformatie te stellen. Hij was overtuigd dat kerkherstel slechts mogelijk was door een verandering in de prediking. Daartoe leidde hij op zijn gymnasium jongeren op. Hij was een bevoegd en zeer bekwaam classicus (De Groot, 1983:126). Hij schaarde zich naast Kuyper in diens ijver voor de Doleantie, nam deel aan het examen van de eerste candidaat van de Vrije Universiteit, J.H. Houtzagers, die hij in 1886 in Kootwijk bevestigde. Kuypers zonen studeerden bij Van Lingen op diens gymnasium te Zetten.

Maar al spoedig kwam het tot een breuk tussen Van Lingen en Kuyper. De eerste herkende zich niet in de koers die Kuyper voor de Doleantie uitzette. Van Lingen had een sterke voorliefde voor het piëtisme, hij was een sterk gevoelsmens en beoefende een stevige vorn van ascese, waarvan hij geen spoor 
terugvond in het streven van Kuyper. Nog voordat er serieus sprake was van een vereniging van dolerenden en christelijk-gereformeerden, had Van Lingen de stap gedaan naar de Christelijke Gereformeerde Kerk. Hij verliet Zetten met zijn geliefd gymnasium, en vond een levenstaak straks in de opleiding van predikanten van de Christelijke Gerefonneerde Kerk, die in 1892 niet meeging met de Vereniging. Hij was het die met Kuypers persoonlijke ambities het best vertrouwd was. Hij was het ook die een zekere invloed uitoefende op Wisse. Beiden tekenden met enkele honderden christelijk-gereformeerden bezwaar aan tegen het besluit tot ineensmelting van de twee kerkengroepen. En beiden hebben hun krachten gegeven aan de voortzetting van de Christelijke Gereformeerde Kerk na 1892. Aan hun inspanning was het mede te dankell dat er van meet af aan sprake was van uitbreiding van de Christelijke Gereformeerde Kerk. Een niet gering aantal christelijk-gerefonneerden dat wèl met de Vereniging was ineegegaan, keerde na verloop van tijd terug. Wij schrijven dit toe aan een duidelijk herkenbare vorm van spiritualiteit, die terugging tot de Afscheiding en via deze tot de Nadere Reformatie, de Dordtse Orthodoxie en de Refonnatie zelf. Het was deze lijn die in de Christelijke Gereformeerde Kerk, zij het niet altijd even duidelijk, herkenbaar werd. Daartegenover ontwikkelde Kuyper met vele van zijn leerlingen met en ná hem een wijze van denken en theologiseren, die weliswaar uitging van refonnatorische motieven, maar die zich gaandeweg van de Reformatie zelf verwijderde en meer en meer aansluiting zocht bij het moderne denken.

\subsection{Spiritualiteit}

We stellen ons ten doel om te trachten het zicht op deze ontwikkelingen te verduidelijken aan de hand van twee voor de kerk gewichtige thema's, waaraan het onderscheid duidelijk kan worden. We denken allereerst aan het thema dat de ecclesiologie raakt, en vervolgens aan dat van de soteriologie. Beide onderwerpen hangen, zoals we zullen zien, ten nauwste samen met het levensgevoel, dat zijn wortels vindt in de vroomheid. We zouden het op een moderne manier kunnen aanduiden als de spiritualiteit. Het verschil dat op dit terrein aan het licht trad, stond ten nauwste met de eerste twee dogmatische onderwerpen in verband. Iemands vroomheid wordt mede bepaald door wat hij denkt en ondervindt van de kerk, en evenzeer door wat hij belijdt en beleeft van zijn doop. Dat wedergeboorte een kernbegrip is uit de spiritualiteit, ligt voor de hand. Hoe zij door de doopsbeschouwing werd beïnvloed, zal nader inoeten blijken.

\section{Het ecclesiologisch motief}

Er bestaat een communis opinıo dat Kuyper en de Kerk volstrekt op elkaar betrokken zijn. "Kuyper en de Kerk zijn bijna correlativa" (Van Leeuwen, 1946: 45). "Kuyper heeft zich van zijn studententijd af tot aan zijn dood bezig gehou- 
den met het probleem van de kerk ..." (Langman, 1950:33). W.H. Velema noemt hem in zijn dissertatie over Kuypers leer van de Heilige Geest "theoloog van de kerk" (Velema, 1957:200). Daarmee is inderdaad Kuypers betekenis getypeerd.

Vanaf zijn publieke optreden heeft hij de kerk op het oog geliad in haar werkelijke situatie, en tegelijk naar het ideaalbeeld dat hij er zich reeds tijdens zijn studie van had gevormd (Praamsma, 1945).

Zijn dissertatie bedoelde een vergelijking te treffen tussen het kerkbegrip van Calvijn en dat van Joh. à Lasco (Kuyper, 1862). De uitgave van de werken van A Lasco bood hem gelegenheid zich nog verder te verdiepen in de betekenis van de reformatorische kerkbeschouwing en de vormgeving ervan in de historische werkelijkheid. Kuyper heeft zich door deze studie gedrenkt in het gereformeerde belijden omtrent de kerk.

De refonnatorische visie op de kerk werd vervolgens aangevuld met hetgeen de na-reformatorische orthodoxie op het gebied van de dogmavorming had gepresteerd. Kuyper heeft zijn bewondering voor het calvinisme nimmer onder stoelen of banken gestoken. Maar hij heeft zich, wat de vorn van dit calvinisme betreft, laten leiden door hetgeen de leidinggevende theologen uit de 'bloeitijd' van de gereformeerde scholastiek hebben nagelaten. Aan hun scholastieke uitgebalanceerde opvattmg van de theologie beantwoordde een krachtige en evenwichtige, gestructureerde kerkvorm.

Kuypers oriëntatie op de Refonnatie is een directe geweest door zijn studie van Calvijn, en een indirecte door zijn grote belangstelling voor de gereformeerde scholastiek. Het is opmerkelijk dat hij in zijn ijver om de gereformeerde theologie tot nieuw leven te wekken een heruitgave deed verschijnen van juist deze theologen. Hij nam de werken van F. Junius, H. Zanchius, G. Amesius, G. Voetius en anderen op in zijn Bibliotheca Reformata. En het waren deze theologen, die voorstanders waren van een krachtig gestructureerd kerkmodel.

\subsection{Kuypers kerkbeschouing: kerk en verkiezing}

Kuypers ideaal om de gerefonneerde theologie tot nieuw leven te brengen, had rechtstreeks betrekking op zijn kerkbeschouwing. Het is bekend wat hem als ideaal voor de theologie voor ogen stond. Hij legde zich erop toe "om de Gereformeerde Theologie, die als zoodanig reeds sinds het midden der vorige eeuw den slaap der tragen sliep, weer wakker te schudden en in rapport te brengen met het menschelijk bewustzijn, gelijk zich dit aan het einde der $19 \mathrm{e}$ eeuw ontwikkeld heeft" (Kuyper, 1908:VI). Kuyper bracht deze gedachte ook voor de kerk als zodanig in praktijk. Hij voelde zich nauw verbonden met de zestiende-eeuwse kerk. Maar deze innige relatie betrof haar belijdenis, waarvan Kuyper oordeelde dat zij telkens op de hoogte van de eeuw gebracht moest wor- 
den. De tijdsduur tussen de zestiende en de negentiende eeuw moest overbrugd worden. Zeer duidelijk is Kuyper daarover geweest in zijn geschrift De revisie van de revisielegende (Kuyper, 1879:146):

Neen, wat we bedoelen is dit. Nu de denkwereld en het leven en dus ons bewustzijn zoo machtige wijziging onderging, ontstaat de zeer ernstige vraag, op wat wijs de door onze vaderen beleden waarheid, die ook wij onveranderd met hen en op hun voetspoor wenschen te belijden, met dit veelszins gewijzigd bewuslzijn in bewuste aanraking en verbinding kan blijven. En toch, dáár en dáárop vooral komt het voor de toekomst der Gereformeerde kerk aan (Augustijn, 1986:71).

Wat Kuyper uit de zestiende eeuw omtrent de kerk had geleerd, had vooral betrekking op de relatie tussen kerk en verkiezing. Calvijn had reeds in de eerste uitgave van de Institutie kerk en verkiezing op elkaar betrokken. In de latere uitgaven van zijn Institutie bleef deze relatie weliswaar materieel bestaan, ofschoon er een formele wijziging optrad. De kerk werd meer dan voorheen door Calvijn beschouwd als een uiterlijk middel, waardoor de verborgen genade van de Geest werkt. Zijn visie op Woord en Geest in hun tweeheid en tegelijk in hun onverbrekelijke verbondenheid, stelde hem in staat on de kerk, wat haar uiterlijke verschijningsvorm betreft, een plaats te geven in het vierde boek.

Ook Kuyper interesseerde zich voor de relatie tussen verkiezing en kerk. Een van de eerste series artikelen die hij schreef (1879-1880), accentueerde zo sterk dat de genade particulier is, dat Kuyper bij zijn benoeming tot hoogleraar aan de Vrije Universiteit niet in aanmerking kwam voor de dogmatische leerstoel (Augustijn, 1986:69). Men vreesde eenzijdigheden. Een volgende serie over het verbond moest evenwicht tot stand brengen. En zijn groots opgezette werk over de gemene gratie maakte duidelijk, dat Kuyper in staat was zijn theologie te integreren in een culturele totaalconceptie, die hoe langer hoe meer zijn finale belangstelling bleek te trekken. Intussen bleef zijn uitgangspunt gelijk. Het was te vinden in zijn relatie van verkiezing en kerk, en het stelde hem in staat om enkele markante punten aan te brengen die voor de gehele opvatting van het neo-calvinisme kenmerkend zouden blijven. Allereerst denken we aan het onderscheid dat hij aanbracht tussen de kerk als instituut en de kerk als organisme. Het zou van grote betekenis blijken te zijn voor de ontvouwing van christelijke actie. De kerk met haar verkondiging van het evangelie werd losgewikkeld van de activiteiten die de gelovigen zelf op de verschillende terreinen van het leven konden ondernemen.

Doordat deze gedachte in verband werd gebracht met die van het onderscheid tussen algemene en particuliere genade, schiep Kuyper de mogelijkheid om ná de mislukking van de Doleantie, die immers ook een afscheiding was geworden, zijn krachten te ontplooien op het terrein van politiek en maatschappij. We kunnen 
deze overstap verklaren door de theologie erachter in het oog te houden. Kuypers belangstelling voor het kerkelijke leven nam af. Ook zijn persoonlijke band aan zijn kerk muntte niet uit door wellevendheid. Hij placht onder kerktijd zijn meditaties te schrijven, dat wil zeggen: hij was met het organisme bezig, meer dan met het instituut.

\subsection{Kuypers visie op de pluriformiteit van de kerk}

Een tweede bijzonderheid waarmee Kuyper zijn visie op het calvinisme meende te kunnen uitbreiden, was de opvatting van de pluriformiteit van de kerk. Zij betekende in feite niets anders dan de algehele berusting in de kerkelijke verdeeldheid. Kuyper bracht de verscheidenheid in verband met de varieteiten in de schepping, en zag er heerlijkheid in. De theologische opvatting omtrent de emst van een schisma werd daardoor ondergraven. Ook deze theorie bood hem de mogelijkheid on de kerkelijke toestand met gereserveerdheid te beschouwen.

Het waren deze punten die vóór de Vereniging van 1892 in de verhouding van Kuyper tot de clristelijk-gereformeerden nog geen rol speelden. Zij bleken eerst daama van betekenis.

Kuyper had zich vóór 1892 nogal eens onleus uitgelaten over de afgescheidenen. Hij bezigde de uitdrukking krank in de levenswortel in de Heraut van 4 januari 1878 met betrekking tot de Christelijke Gereformeerde Kerk. Hij oordeelde dat deze kerkformatie verzuimd had eigen positie ten opzichte van de staat te verduidelijken. Kuyper oordeelde dat artikel 36 van de geloofsbelijdenis herzien diende te worden. En de christelijk-gereformeerden hadden verzuimd zich confessioneel ten overstaan van de overheid te verantwoorden. $\mathrm{Zij}$ hadden evenmin de dwalingen die sinds de zestiende eeuw waren opgekomen in hun belijdenis weersproken. En ze hadden nagelaten hun afscheiding van de Hervormde Kerk confessioneel te verantwoorden.

Het is de uitdrukking krank in de levenswortel geweest die zich vastgehecht heeft in menige christelijk-gereformeerde ziel. Het uitgaan uit de Hervormde Kerk vloeide rechtstreeks voon uit hun handhaven vall de belijdenis op het stuk van de kerk. Zij hadden ook de overtuiging dat het oude artikel 36 van de belijdenis betrekking had op een theocratische beschouwing van de verhouding tussen kerk en staat. Deze visie wensten de christelijk-gereformeerden niet los te laten. Wat dit betreft, waren zij in zekere zin conservatief te noemen, terwijl Kuypers kerkconceptie volledig rekening hield met de moderne democratie, die niet meer ontkend kon worden. Op het punt van de interpretatie van artikel 36 wezen de christelijk-gereformeerden Kuypers beschouwingen af

Toen Kuyper in 1878 zijn oordeel over de Christelijke Gereformeerde Kerk uitsprak, was de strijd over het herstel van de Hervonnde Kerk begonnen. 
Uitgaande van zijn conceptie van het organisme van de kerk besloot hij het hiërarchische bestuur van de kerk terzijde te stellen. De secundaire betekenis die Kuyper toekende aan de kerk als instituut, stelde hem in staat on in de praktijk, al naar gelang de omstandigheden vereisten, zijn visie op de kerkvorm bij te stellen.

Het meesterplan was in de jaren zeventig gereed. De uitvoering ervan hing af van de meest gunstige omstandigheden, zoals blijkt uit een brief aan Groen van Prinsterer:

Thans moet ik eerst onze Kerken en fondsen nog in veiligheid brengen. Daaraan ben ik bezig. Doch eer dit in zulk een lichaam als onze Gemeente gereed is, moet er veel gesproken, geschreven, georganiseerd. Mijn plan is de breuke te vertragen, tot alles in gereedheid is. Dan zal het op autonomiseering onzer gemeente en daaruit volgende splitsing in 3 groepen uitloopen. Tegen deeling van het Kerkelijk Goed zal ik me niet verzetten, mits men ons in de breuke steune. Daama zal hereeniging met de Gescheidenen vanzelf komen (Goslinga, 1937:195).

In het eind van de jaren zestig vertoont Kuypers praktische visie op de kerk independentistische trekken. In de jaren zeventig hebben zijn plannen iets in zich van opportunisme. De jaren tachtig brachten een ongedachte wending tot stand, toen de Doleantie een afscheiding werd. De jaren negentig laten zien dat Kuypers kerkconceptie hem veroorloofde zich op het bredere terrein van het organisme te begeven, namelijk in de politiek.

Dat dit alles gedragen werd door één visie, kan niet ontkend worden. Nog minder is aan twijfel onderhevig het feit dat een geniaal strateeg in actie was gekomen, een man met een breed-culturele blik, die op het juiste moment zijn visie kon inzetten in een vorm die aan de omstandigheden was aangepast. Juist op dit punt botste zijn kerkidee op die van de afgescheidenen. Deze waren door hun confessionele standpunt gebonden wat hun kerkbeschouwing betreft. Zij misten de mogelijkheid, wellicht ook de vaardigheid, om hun inzichten aan te passen aan de omstandigheden. Daardoor had hum beschouwing iets wat op de buitenstaander de indruk kon maken van starheid en onverzettelijkheid. De vraag is echter of dit ook inderdaad het geval was.

Kuyper laakte in het kerkbegrip van de christelijk-gereformeerden het gebrek aan tijdbetrokkenheid. Hun belijdenis lag vast in de historische betekenis die zij in de zestiende eeuw had verkregen terwijl Kuyper haar als "onveranderde waarheid" wilde belijden in overeenstemming met het "veelszins gewijzigde bewustzijn" van de eeuw (Van't Spijker, 1992b:89). Hij meende ook dat de Afscheiding confessioneel in gebreke was gebleven in een verantwoording van haar daad. Daarmee was in feite een heftig verwijt uitgesproken aan het adres van de afgescheidenen. Dit trof te pijnlijker omdat zij hun afscheiding niet beschouwden als 
een daad van separatisme, maar integendeel als een blijk van gehoorzaamheid aan de belijdenis der vaderen. Het is niet moeilijk om daarvoor allerlei bewijzen aan te dragen uit de Acte van Afscheiding en uit de geschriften van Hendrik de Cock zelf.

\subsection{De Acte van Afscheiding als oecumenisch document}

Men zou de Acte van Afscheiding een oecumenisch document kunnen noemen (De Cock, 1984:589-623). De ondertekenaars verklaren "gemeenschap te willen uitoefenen met alle ware Gerefonmeerde ledematen, en zich te willen vereenigen met elke op Gods onfeilbaar woord gegronde vergadering, aan wat plaatse God dezelve ook vereenigd heeft" (De Cock, 1984/1986:608). Aan hen allen reiken zij de broederhand, en zij vragen de hunne (De Cock, 1984/1986:611).

Op de basis van Schrift en belijdenis vraagt men om de instemming met alle gereformeerde belijders. We moeten aannemen dat dit de afgescheiden broeders ernst is geweest. Hendrik de Cock stond op geen ander standpunt. Hij heeft onder de afgescheidenen van het eerste uur een samenbindende invloed uitgeoefend, waarvan wij de betekenis niet gemakkelijk kunnen overschatten. In de 'crisis der jeıgd' die de Afgescheiden Christelijke Kerk doormaakte, heeft hij zichzelf verloochend, en tegelijk de strijd aangebonden tegen het opkomende independentisme in eigen kring. Hij was daartoe in staat door zijn eigen theologische opvattingen. Deze werden achtereenvolgens gevormd door de Nadere Reformatie, door de Dordtse Orthodoxie en door de Reformatie zelf (Van 't Spijker, 1984b:113-119). Van betekenis was daarbij ook de invloed van het Nederlandse Réveil op De Cock.

We constateren dat er punten van overeenkomst waren met Kuyper. Maar de verschilpunten vallen ook in het oog. Kuyper heeft weinig positieve vrucht binnengehaald van de Nadere Reformatie. De Cock kwam tot verandering mede door het lezen van de geschriften van reformatoren en vertegenwoordigers van de Nadere Reformatie zelf.

\subsection{Kuyper en De Cock}

Kuyper koos als uitgangspunt de Refonnatie, maar dan op een eigentijdse manier ingevoegd binnen de situatie van de West-Europese cultuur. De Cock plaatste zijn reformatische optreden binnen het raam van de Nederlandse kerkelijke situatie, waarbij de Orthodoxie en de Nadere Reformatie voor hem bepalend waren. Voor Kuyper ging het om een verkiezingsidee. Voor De Cock prevaleerde de verbondswerkelijkheid.

Dit had voor het kerkbegrip nogal belangrijke consequenties. Wie uitgaat van de verkiezing in het ontwerp van de kerk, behoudt alle mogelijkheden tot speculatie. 
Kuyper heeft daarvan nuim gebruik gemaakt. Wie echter uitgaat van de historische situatie, zoals deze door het verbond Gods gestempeld is, kan grotere waardering koesteren voor de volkskerk. In die richting kon De Cock denken met zijn opvatting van het verbond. Hij zag het verbond der genade als een zaak van de relatie waarin de mens geplaatst is tegenover Christus en zijn belofte. Deze basis was voor hem objectief, vastliggend in de belofte van God. Daarbij maakte De Cock wel onderscheid tussen de belofte zoals wij die 'in aanbieding' hebben, en de belofte zoals deze vervuld wordt in de weg van persoonlijk geloof (De Cock, 1986:551).

Het bekende conflict tussen De Cock en H.P. Scholte in 1836/37 leidde tot een verwijdering tussen de beide broeders, die aan de wieg van de Afscheiding hadden gestaan. Scholte nam een standpunt in dat deed denken aan de vroegere independenten, en evenzeer aan de opvattingen van Kuyper een halve eeuw later (De Cock, 1984/1986:521-556). En dit conflict maakt duidelijk dat De Cock niet door separatisme werd geleid, maar door een zuiver reformatorisch kerkelijk besef. De Cock wees het Labadisme, het Independentisme en het Donatisme af. Daarmee had hij alle separatistische bewegingen uit de kerkgeschiedenis aan de kant geschoven. En hij had zonder aarzeling gekozen voor het kerkelijke denken, zoals dit in de belijdenis was verankerd. Voor hem was dit geen belijdenis die slechts historische waarde had. Hij paste haar toe op de concrete toestand van zijn eigen tijd. Hij vond het niet noodzakelijk om de belijdenis op dit punt aan te vullen. Zijn visie op de verhouding van kerk en staat maakte het evenınin noodzakelijk om artikel 36 van de belijdenis te wijzigen.

Dit kerkbegrip was niet los verkrijgbaar. Het was nauw verbonden aan het Schriftbeginsel, en vooral aan het grondprincipe van de vrije genade. Predikers van de genade zijn altijd strijders voor de kerk geweest. Zo was het bij Augustinus, bij Calvijn, bij John Knox. Zo was het ook bij De Cock. En daarmee heeft hij aan de Afscheiding een stempel opgedrukt, dat de Christelijke Gereformeerde Kerk bewaard heeft voor separatisme. Tegenover het kerkbegrip van Kuyper, aangepast aan het denken van de eeuw, stond dit klassieke belijden omtrent de kerk, in overeenstemming met de Nederlandse geloofsbelijdenis.

\subsection{De Afscheiding - geen separatisme}

Toen in 1892 de kleine groep van christelijk-gerefonneerden onder leiding van Wisse en Van Lingen weigerde met de Vereniging mee te gaan, deed zij dit met een beroep op het 'beginsel van de Afscheiding'. Daarnee was dus geen separatisme bedoeld. Men verklaarde in 1892 dan ook niet dat men van een vereniging afkerig was. Maar men wees déze vereniging, op dit moment en naar déze methode af. Het 'sluit nu nog niet de door zo velen gevreesde vereeniging' was dan ook geen keus voor het kerkelijk isolement. Het was de uitdrukking van de 
wens om vijftig jaren ná de Afscheiding te blijven leven uit hetzelfde kerkelijke beginsel.

Was dit geen kortzichtigheid? Verdiende dan de belijdenis uit de zestiende eeuw geen aanvulling of wijziging op het punt van de kerk? Op deze vraag antwoordde men met een overtuigd: neen! In de belijdenis van de kerk was tegelijk iets gezegd omtrent haar structuur, die er immers op gericht was om een geestelijke bestuurswijze te bevorderen (artikel 30 Ned. Geloofsbelijdenis). De verbreiding van de ware leer en de onderhouding van de ware religie waren ermee gemoeid.

Op deze betekenis van de kerk als instituut viel voor de afgescheidenen de nadruk. Zij vonden haar verwoord in de artikelen ontrent de ware kerk. En zij vonden tegelijk in deze kerkopvatting een sterke stimulans om de ware eenheid van de kerk na te streven. Kuyper wilde het juk van hiërarchie afwerpen. Het was op zichzelf beschouwd een edel streven. Maar voor de afgescheidenen was dit nog iets anders dan hetgeen de belijdenis leerde omtrent het juk van Christus, dat men op zich had te nemen. En zij verstonden met de refonmatoren dit juk van Christus niet slechts in een zeer persoonlijke zin als een nodigende belofte voor de vermoeide ziel (Matteüs 11:28-30), maar zij vatten het opnemen van het juk van Cluristus op in eell zuiver kerkelijke betekenis

Daarmee deden zij recht aan de tweevoudige reeks waarvan in artikel 29 van de Ned. Geloofsbelijdenis sprake is. Daar worden immers de kenmerken van de kerk vrijwel in één adeın genoemd met de kenmerken der kinderen Gods. Men moet niet alleen spreken over de ware kerk, maar evenzeer over het levend lidmaat zijn van de kerk.

En men hanteerde dit confessionele kerkbegrip in de wetenschap dat men in de kerk moest zijn met haar prediking, sacramentsbediening en haar tuchtoefening, om werkelijk rust voor de ziel te vinden. Zo vonden zij in hun kerkbeschouwing een garantie voor de vrije prediking van het evangelie zelf. En daarvan verwachtten zij heil voor volk en vaderland. Niet de kerkidee was het die hen trok, naar wijsgerige trant opgevat en afgeleid van de idee van de verkiezing zoals bij Kuyper, maar de werkelijkheid van de kerk naar de belijdenis van het geloof, zoals zij in de traditie van de Afscheiding tot uitdrukking was gekomen. Zo speelde het dogina van de kerk een rol in 1892, toen men besloot om zich van de Vereniging afzijdig te houden. De kerk als instituut waarin naar het welbehagen van God het heil beleden, gewerkt en beleefd wordt: zij speelde in 1892 een rol zoals zij dit sinds 1834 reeds gedaan had.

\section{Het soteriologisch motief - doop en wedergeboorte}

In nauwe relatie met de belijdenis van de kerk stond bij Kuyper het leerstuk van de doop. Beide stukken van de leer stonden bij hem onder beheersing van de uit- 
verkiezing. Kuypers scheppende geest wist ze in te passen in het geheel van zijn systeem. Daarin lag het volle accent op de eeuwigheid. De verkiezing had daar vanzelf een plaats. Maar ook de rechtvaardiging was een zaak die in de eeuwigheid reeds beslist was. In relatie daarmee stond heel de conceptie van de doop en de wedergeboorte (Smilde, 1946:65-117).

Voor degenen die in 1892 zichzelf als de voortzetting van de Christelijke Gereformeerde Kerk beschouwden, lag op dit punt een overwegend bezwaar om met de Vereniging mee te gaan. Het is vooral Van Lingen geweest die tegen dit overmatig gewicht op een denken vanuit de eeuwigheid bezwaar aantekende. Hij hechtte grote waarde aan de ervaring van het geloof. En hij bestreed als een van de eersten met kracht Kuypers visie op de doop in verband met de wedergeboorte. Hij had dit reeds in zijn eigen kleine maandschrift Petahja gedaan. In 1892 en daarna schreef hij uitvoerig over de kwestie in Het Wekkertje.

Kuyper schroomde niet om krasse uitspraken te gebruiken. In zijn geschrift over doop, belijdenis en avondmaal, Voor een distel een mirt, ontwikkelde hij zijn zienswijze over de genade der wedergeboorte, die hij als het inplanten van een kiem van het geloofsvermogen beschouwde. Bij de doop moet men veronderstellen, vertrouwen, ja geloven dat God het kind de genade van de wedergeboorte schonk. De heilige doop vindt zijn grond in het genadewerk dat God reeds aan het kind volbracht (Kuyper, 1922:60 e.v.). Wanneer bij de doop de Heilige Geest niet wordt ontvangen, dan is de doop een nagebootste doop en geen christelijke doop. De doopgenade dient tot versterking van het reeds aanwezige geloofsvermogen (Kuyper, 1922:66). Weliswaar weten wij niet met zekerheid dat een kind werkelijk geheiligd is in Christus, maar wij hebben het kind als zodanig te beschouwen. Op die grond vragen we de doop aan. Bij de opvoeding van het kind kunnen we alleen werkelijk vermanen, wanneer we veronderstellen dat er een verborgen genade in het kind aanwezig is. De opvoeding strekt alleen om dit verborgen genadezaad te besproeien (Kuyper, 1922:80). Ook op andere plaatsen heeft Kuyper met een stelligheid die bij het vaststaande systeem paste, deze opvatting verdedigd (Kuyper, 1890:14; 1892:9-15). Het was een artikel in De Heraut van 28 september 1890 (nr. 666), waarin Kuyper als zijn mening te kennen gaf dat iemand die bleef vasthouden aan de mening, dat een kind zou mogen gedoopt worden zonder dat daarbij zijn verkiezing werd verondersteld, niet met een eerlijke consciëntie in de Gerefonneerde Kerken kon blijven. Kuyper sprak uit dat de Gereformeerde Kerken vanouds 'vlak het tegendeel' leerden en beleden.

Kuyper stond met zijn opvattingen niet alleen. Ze werden met kracht verdedigd binnen de Gereformeerde Kerken ná de Vereniging (Bouma, 1967:159). Vrij excessieve opvattingen werden gelanceerd, met name door Kuypers zonen. Kuyper kon inderdaad teruggrijpen op een zienswijze die ook wel in de 
scholastieke gereformeerde theologie werd aangetroffen. Zo kon ook Voetius, de grootmeester van de gereformeerde orthodoxie, in zijn dogmatische disputaties zeer diepgaande betogen leveren over de geloofshebbelijkheid (habitus) en over de daad van het geloof (actus fidel). Voetius leerde ook dat het geloofsvermogen in de ziel van de uitverkoren zondaar werd gelegd. Hij sprak zelfs over de wedergeboorte in de ziel van Paulus en in die van de moordenaar aan het kruis, vóór hun bekering (Voetius, 1887:262). Wat dit betreft, deed hij voor Kuyper niet onder.

Maar er was een groot verschil. Kuyper hanteerde deze begrippen niet in de marge van zijn theologie, zoals bij Voetius wèl het geval is, maar hij bouwde ze om tot een hecht systeem, dat geheel en al beheerst werd door motieven vanuit de eeuwigheid die met de verkondiging van het evangelie slechts in zoverre samenhingen, dat de laatste slechts diende om de wedergeboone te wekken, niet om haar te werken. Daarnee was de effectiviteit van Woord en Geest in hun onderlinge samenhang gebroken. Daanmee was de kracht en het missionaire élan van de prediking van het Woord ook enstig te kort gedaan. En daannee werd een element aan de beschouwing van de gemeente ontnomen, dat bij Voetius alle gewiclt had ontvangen: dat van de noodzaak èn van de belofte van de wedergeboorte en bekering.

Kuyper keerde tot Voetius terug, het is waar. Maar hij bracht Voetius' ideeën over in zijn eigen groots opgezette systeem. En daarmee kwam de veronderstelde wedergeboorte op een plaats te staan, die zij voorheen nimmer had bekleed. Daardoor werd ook de prediking van een wezenlijke kracht beroofd. En daardoor kwam er een gemeentebeschouwing tot stand, die aan de emst van de prediking serieus te kort deed. Het maakt een groot verschil welk standpunt men inneemt bij de visie op de gemneente en de aan haar toekomende belofte: dat van Kuyper of dat van de afgescheidenen

De laatsten hadden altijd grote belangstelling gehad voor de vragen van de subjectieve soteriologie. Het heil wordt verkondigd. Maar het moet ook geloofd worden. Het geloof rekent niet met een veronderstelling omtrent de aanwezigheid van de genade van God: het rekent met de vastheid van de belofte. Met deze beschouwing was recht gedaan aan de reformatorische ontdekking van Luther, dat God met ons handelt op de manier van de belofte van het evangelie, en dat wij slechts met God kunnen handelen op de manier van het geloof in zijn belofte.

De afgescheidenen hadden daarbij ook op een bepaalde manier de theologie van de Nadere Reformatie gehonoreerd. Voor hun dogmatisch bewustzijn vertegenwoordigde de gereformeerde scholastiek een waardevol element. Zij schreven de werken uit deze periode van de geschiedenis der theologie zelfs voor bij hun onderwijs. Maar zij hechtten niet alleen waarde aan de zuivere leer, doch ook 
aan het zuivere leven, zoals dit een accent had ontvangen in de Nadere Reformatie. Wel twee generaties afgescheidenen waren groot geworden met het gedachtengoed van het leerboek dat W. à Brakel had geschreven, en waarin orthodoxie en bevindelijkheid elkaar ontmoetten: Redelijke Godsdienst. Het redelijke daarin berustte niet op rationalisme, maar op de kennis van het geloof die uit de wedergeboorte voortvloeit. Geen rechtvaardiging van eeuwigheid, geen veronderstelde wedergeboorte kwam daar aan te pas.

Van Lingen was, wat de beschouwing van de wedergeboorte betreft, van precies het tegenovergestelde gevoelen als Kuyper. Hij was geen dogmaticus, maar een kenner van de klassieke talen als weinigen. Zijn studie over de wedergeboorte berust op exegese. Van Lingen was ook een réveilman, die grote waardering koesterde voor Spener en Francke, de vertegenwoordigers van het achttiende-eeuwse piëtisme. Zijn eigen bekering had met een sluimerende wedergeboorte niets te maken. Hij werd door een zware crisis geleid. Hij stelde zijn eigen weg niet als een voorbeeld. Maar het was hem wel geheel onmogelijk om aan te nemen dat iemand wedergeboren kon zijn, zonder dat dit op de een of andere manier in het leven openbaar werd.

In dit stuk van zaken ontmoetten zijn denken en dat van Wisse, de afgescheiden predikant, elkaar. De laatste was afkomstig uit de kringen van de zogenaamde Kruisgezinden. Daar was sprake van een krachtige bevindelijke vroomheid, die het gevoel van de gelovige niet uitschakelde, maar normeerde. Ook Wisse had van Kuypers wijsgerige theologie geen hoge dunk. Hij is door Van Lingens kritiek op Kuyper tot het besluit gekomen om niet met de Vereniging mee te gaan. Ook voor hem ging het in Kuypers leer inzake wedergeboorte en doop om een zaak waartegen hij een overwegend bezwaar koesterde. Zo waren het vooral deze twee dogmatische gezichtspunten die een grote rol speelden bij de kwestie van verenigen (kerkelijke eenheid) en niet verenigen (kerkelijke scheiding).

\section{Dogmatiek, kerkelijke eenheid en vroomheid}

\subsection{Dogmatische kwesties}

Twee kwesties dienen hierbij nog aan de orde gesteld te worden. De eerste is die welke door de synode van de Christelijke Gereformeerde Kerk werd aangeroerd, toen zij in haar antwoord op de bezwaren stelde "dat men geen kerkelijke vereeniging mag weigeren om redenen, waarom men eene kerkelijke vereeniging niet zou mogen verbreken" (Handelingen, 1988:X,18). De redenering lijkt sluitend. Maar doet zij recht aan de omstandigheden? Was het verkeerd dat Wisse en Van Lingen op deze dogmatische punten meer zekerheid wilden hebben? Méér dan eenmaal heeft Van Lingen te kennen gegeven dat Kuypers invloed beslist niet onderschat mocht worden. Hij was - het was geen toeval - 
van verschillende synoden achter elkaar de voorzitter. Hij had zeer geprononceerde opvattingen, en hij gebruikte ook zeer persoonlijke methoden om tegenstanders uit te schakelen. Men kan over dogina's niet spreken alsof men ze kan scheiden van de personen die ze aanhingen. De historische situatie behoefde men niet uit het oog te verliezen. En juist die omstandigheden noopten de bezwaarde broeders in 1892 om te zeggen: nú nog niet, en: niet volgens déze methode. In een situatie waarin kerkelijke eenlıeid bestaat als een werkelijk gegeven, liggen sommige dingen anders als in een situatie waarin men kerkelijke eenheid zoekt en daarbij garanties vraagt dat een als onconfessionele leer gebrandmerkte opvatting geen heersende rol zal spelen in de verenigde kerken. De geschiedenis ná 1892 heeft in de Gerefonneerde Kerken overduidelijk aangetoond, dat er op z'n minst een krachtig element van waarheid school in de aangevoerde bezwaren, die op dognatisch terrein lagen.

\subsection{Kerkscheiding - separatisme of voortvloeisel van de Afscheiding?}

De tweede kwestie die we in dit verband noemen, betreft de beoordeling van de daad der bezwaarden. Was hun daad van 'kerkscheiding' separatisme, of mag zij beschouwd worden als een voortvloeisel van de Afscheiding zelf?

Wanneer men van oordeel is dat de Afscheiding van 1834 een daad van separatisme was, dan is het voor de hand liggend om ook het optreden van Wisse en Van Lingen in 1892 als scheurnakerij te bestempelen. Wij zijn echter van oordeel dat de daad van Hendrik de Cock in 1834 berustte op gehoorzaamheid aan de eis die de belijdenis inzake de kerk stelde. Hierboven zagen we reeds dat De Cock het standpunt van de Donatisten uit de tijd van Augustinus afwees. Hij keerde zich even fel tegen het labadistische denken dat hij in eigen kring aantrof. Kuyper was in sommige opzichten zeer duidelijk een aanhanger van independentistische gedachten, die De Cock verfoeide.

Kortom, de vader van de Afscheiding wilde zich bewegen op zuiver kerkelijke paden. Hij brak met de confessionele ontrouw van de Hervormde Kerk. Hij koos voor de kerkelijke structuur die de Refonnatie van de zestiende eeuw hem had voorgehouden. Hij vertegenwoordigde het beginsel van de Afscheiding, niet dat van het separatisme

Het beroep op het 'beginsel van de Afscheiding', dat in 1892 werd gehoord bij de kleine groep die weigerde mee te gaan met de combinatie van twee kerkengroepen door middel van een synodaal besluit, was legitiem. En dit gold des te meer, omdat achter dit beginsel niet alleen maar een dogmatische of theologische constructie lag, hoe zwaar men dit op zichzelf ook wilde beoordelen. Maar achter de handhaving van het dogmatische beginsel ging een gewichtig moment schuil, dat rechtstreeks te maken had met de geaardhcid van de gereformeerde vroomheid. Wij spreken vandaag veelal van spiritualiteit. Welnu, deze was ook 
in geding toen men vooralsnog weigerde mee te gaan met de stap die door zo velen in het land werd gedaan.

\subsection{De geaardheid van gereformeerde spiritualiteit}

De verhouding van het dogma van de kerk tot de gereformeerde vroomheid lijkt op het eerste oog niet doorzichtig. Toch is deze er wel terdege. Naar gereformeerde opvatting is een geestelijk mens ook een kerkelijk mens. Gerefonmeerde spiritualiteit wordt gevoed in en door de kerk. De geloofsbelijdenis brengt het onderhouden van de ware religie zelfs in verband met de kerkelijke structuur. Omdat het De Cock in al zijn activiteiten te doen was om de kerk en niet om het conventikel, kostte zijn strijd hem zo veel moeite en bracht zij hem zo veel zorgen. Naar de kant van de overheid pleitte hij voor de vrijheid van de verkondiging van het evangelie. Naar binnen voerde De Cock een strijd om zuiver kerkelijk te blijven denken. Daarachter ging geen kerkisme schuil, maar een zuiver verstaan van de betekenis van de kerk als geloofsgemeenschap, als liefdesgemeenschap en als tuchtgemeenschap.

In nauw verband met deze opvatting van de kerk als constituerend voor de vroomheid, stond ook de strijd die De Cock voerde tegen het independentistische streven van H.P. Scholte. Wij herkennen in enkele van diens opvattingen heel duidelijk de dogmatische positie die Kuyper later imnam. Bekend zijn in dit verband de artikelen die in 1837 door de synode van Utrecht werden aangenomen (Handelingen, 1984:103-113). De Cock stond op deze synode vrijwel alleen tegenover het standpunt van Scholte. Zijn visie werd echter door latere synodes overgenomen. Zij kwam hierop neer, dat de gemeente haar fundament niet bezit in een wilsakte van de mens die tot die gemeente toetreedt, maar in de belofte van God. Daarmee stond het verbond der genade als basis van de kerkbeschouwing vast Maar die belofte van het verbond markeerde ook een onderscheid dat dwars door de gemeente heen liep. Hoe staat men tegenover haar? Alle leden van de gemeente moet men als zodanig erkennen, zolang zij niet afgesneden zijn. Maar dit zegt op zichzelf nog niet alles. Immers die belofte kan men bezitten "in aanbieding", men kan haar ook bezitten "in toepassing" (Handelingen, 1984:110). Blijkbaar wilde De Cock rekenen met het onderscheid in de gemeente, en zijn pastorale praktijk daarop afstemmen.

Deze zelfde kwestie speelde ook in 1892. Zij vormde de achtergrond van het verzet tegen Kuypers opvatting omtrent de veronderstelde wedergeboorte. Toen Van Lingen en Wisse verzet aantekenden tegen een dogmatische constructie, kwam dit verzet ten diepste voort uit een motief dat ontleend was aan de gereformeerde vroomheid, zoals deze een werkelijkheid moet zijn in de gemeente. Zij lieten zich daarbij leiden niet door een idealistische opvatting van de gemeente op grond van een verkiezingsidee, maar zij gingen uit van de werkelijkheid van Gods 
verbond, en van de noodzakelijkheid van het leven van het geloof uit de belofte. Zó komt immers Christus tot ons 'bekleed met zijn evangelie', of 'in het gewaad van de Heilige Schrift'. Het geloof leeft niet van ideeën, hoe goed en hoe christelijk die ook mogen zijn, het vindt zijn grond in de belofte van God. Zo verdwijnt elke mogelijkheid tot een speculatieve benadering van de gemeente in pastoraat en prediking. Maar zo komt anderzijds de zekerheid van het geloof niet te berusten op een indirecte weg van kenmerken en nog eens kenmerken van de kenmerken. De zekerheid berust dan op het vaste vertrouwen in de beloften van God, die Hij tot onze troost rijkelijk in zijn evangelie heeft geopenbaard.

Wat Luther in zijn strijd om de heilszekerheid had ontdekt, namelijk de vastheid van de beloften van God, kwam op een eigentijdse manier in 'het beginsel van de Afscheiding' weer naar voren. Het was de grondslag van de ware vroomheid die hier werkelijk in geding was. Het dogma vroeg om verankering in de vroomheidsbeleving. En Kuypers conceptie kon de hoop daarop niet bevestigen. Zo was naar onze overtuiging in 1892 zeker sprake van een dogmatisch motief en zelfs van verscheidene dogmatische motieven. Maar deze hingen op het nauwst samen met de spiritualiteit die in de kerken van de Afscheiding was gevoed.

\section{Slotbeschouwing}

Ten slotte rest de vraag of het 'niet meegaan met de Vereniging' daarom ook met name geen gevaar inhield voor een versmalling van de vroomheid. Gereformeerde vroomheid of spiritualiteit heeft een vaste relatie met het gereformeerde dogma. Maar zij kan slechts floreren, wanneer aan de katholiciteit van de vroomheid geen afbreuk wordt gedaan. Was de 'standvastigheid' die betoond werd door niet mee te gaan en een eigen, vrij kleinschalig kerkelijk leven op te bouwen ook niet een minstens evell grote bedreiging voor de zuivere vroomheid? Zij zou dit naar onze overtuiging geweest zijn, wanneer zij niet was voortgekomen uit het zuivere en op katholiciteit gerichte streven om de hele kerk vast te houden. Dit was het beginsel van de Afscheiding van 1834. Toen het door enkelen in 1892 werd vastgehouden omdat men het niet kon of wilde prijsgeven, geschiedde dit niet uit een latent separatisme. Men was immers niet tegen elke vereniging gekant. Maar tegen déze, op dit moment en naar déze methode. Een beginsel behoeft niet noodzakelijk van inhoud of kwaliteit te veranderen, wanneer het door slechts weinigen wordt aangehangen. Ook zij die als wens uitspraken om 'nu nog niet' met de Vereniging mee te gaan, deden dit uit liefde tot de éne kerk, uit liefde ook tot de eenheid van die ene kerk.

De geschiedenis van 1892 ligt nu honderd jaar achter ons. De dognatische zwaartepunten liggen ook binnen kerken van gereformeerd belijden elders. $\mathrm{Zij}$ zijn verschoven in de richting van een meer open subjectiviteit. Ze hebben een krachtiger ethisch accent gekregen. Juist daarom blijft van eminent belang dat de 
gereformeerde traditie haar visie op de kerk blijft hanteren, niet vanuit een idealistisch verkiezingssysteem, maar vanuit een realistische verbondsbeschouwing, die de waarde van de belofte weet te schatten en de noodzaak van de wedergeboorte niet vergeet, juist omdat zij beloofd is. Een missionaire kerk zal na honderd jaar in vertrouwen verder kunnen gaan, gelovend in de kracht van het Woord, waardoor zij zelf tot aanzijn is geroepen.

\section{Bibliographie}

ACTA van het synodaal convent (1887) en van de voorlopige synoden van de Nederduitsche Gereformeerde Kerken (1888-1892) Met bijlagen en registers. 1985. Kampen/Leusden Kok

AUGUSTIJN, C 1986 Kerk en godsdienst (In Bakker, W. De Jong, O.J, Van 't Spijker, W \& Wolthuis, L.J red., De Doleantie van 1886 en haar geschiedenis Kampen : Kok p. $41-75$.)

BAKKER, W., DE JONG, O J, VAN 'T SPIJKER, W \& WOLTHUIS, L. J red., 1984 De Afscheiding van 1834 en haar geschiedenis Kampen. Kok

BOUMA, H 1967 De vereniging van 1892 Een episode uit de geschiedenis van het oecumenische streven van de 'afgescheiden' en de 'dolerende' kerken in Nederland Groningen De Vuurbaak

DE COCK, H 1984/1986 Verzamelde Geschriften, Deel 1 en Deel 2 Voorzien van inleidingen en aantekeningen door $D$ Deddens, $W$ van 't Spijker, M Drayer, J C L Starreveld, $H$ van Veen en $M$ te Velde, met medewerking van $H$ Bouma en $H$ Natzijl Houten : Den Hertog

DE GROOT, A $1983^{2}$ Frederik Philip Louis Constant van Lingen (In Nauta, D, De Groot, A., De Jong, O J., Van der Linde, S \& Posthumus Meyjes, GHM red., Biografisch Lexicon voor de geschiedenis van het Nederlandse Protestantisme, deel I Kampen Kok p. 126-128)

DRAYER, M \& VAN 'T SPIJKER. W red. 1982 En toch niet verteerd Uit de geschiedenis van de Christelijke Gereformeerde Kerken sinds 1892 Kampen Kok

DRAYER, M \& VAN 'T SPIJKER, W. red. 1984. In trouw gescheiden. Kampen : Kok.

ENDEDIJK, H.C 1990. De Gereformeerde Kerken in Nederland Deel 1, 1892-1936. Kampen : Kok

GOSLINGA, A. 1937 Briefwisseling van Mr G Groen van Prinsterer met Dr A Kuyper 1864-1876. Kampen: Kok

HANDELINGEN en verslagen van de Algemene Synoden van de Christelijke Afgescheidene Gereformeerde Kerk (1836-1869) met stukken betreffende de synode van 1843, bijlagen en registers 1984. Houten/Utrecht : Den Hertog.

HANDELINGEN van de Synoden der Christelijke Gereformeerde Kerk in Nederland 1872 18921988 Kampen Kok

KOK, J.H 1939 Uit de geschiedenis van de Gereformeerde Kerken in Nederland 1882-1892 en 1893-1902, samengesteld uit gepubliceerde geschriften Kampen : Kok

KUYPER, A 1892 E voto Dordraceno Toelichting op den Heidelbergschen Catechismus. Derde deel Kampen : Kok

KUYPER, A. $1908^{2}$ Encyclopaedie der Heilige Godgeleerdheid Eerste deel, inleidend deel Kampen : Kok

KUYPER, A $1922^{5}$ Voor een distel een mirt Geestelijke overdenkingen bij den Heiligen Doop, het doen van belijdenis en het toegaan tot het Heilig Avondmaal Kampen Kok KUYPER, A 1890. Separatie en Doleantie Amsterdam Wormser 
KUYPER, A 1862 Disquisitio historico-theologica exhibiens Joannis Calvini et Joannis à Lasco de ecclesia sententiarum inter se compositionem. 's-Gravenhage : Nijhoff/Amsterdam : Muller.

KUYPER, A 1879. Revisie der revisie-legende Amsterdam : Kruyt

LANGMAN, H J 1950 Kuyper en de volkskerk. Een dogmatisch-ecclesiologische studie Kampen Kok

PRAAMSMA, L 1945 Abraham Kuyper als kerkhistoricus Kampen : Kok

RUITER, W 1965. De man in de schaduw Ds Van Lingen strijder voor het Christelijk Middelbaar Onderwijs en Kerkherstel. Franeker : Wever

SCHRAM, P.L red. 1992. Documemtatieblad voor de Nederlandse Kerkgeschiedenis na $1800,15(36)$ Kampen : Kok

SMILDE, E 1946 Een eeuw van strijd over verbond en doop Kampen : Kok

VAN LEEUWEN, P A 1946. Het kerkbegrip in de theologie van Abraham Kuyper. Franeker : Wever.

VAN 'T SPIJKER, W. 1982. De strijd om het voortbestaan (In Drayer, M., Van 't Spijker, W. \& Velema, J.H. En toch niet verteerd Uit de geschiedenis van de Christelijke Gereformeerde Kerken sinds 1892 . Kampen : Kok p. 9-27)

VAN 'T SPIJKER, W. 1984a Theologie en spiritualiteit van de afgescheidenen. ( $m$ Bakker, W., De Jong, O J, Van 't Spijker, W \& Wolthuis, L J red, De Afscheiding van 1834 en haar geschiedenis. Kampen Kok p 147-179.)

VAN 'T SPIJKER, W 1984b. De dogmatische aspecten van de Afscheiding. (ln De Groot, A \& Schram, P L Aspecten van de Afscheiding Franeker: Wever p. 105-128.)

VAN 'T SPIJKER, W. 1992a 1892: Spiritualiteit in het spel? (In Schram, PL red., Documentatieblad roor de Nederlandse Kerkgeschiedenis na 1800, 15(36):47-66. Kampen : Kok )

VAN 'T SPIJKER, W 1992b Catholicity of the Church in the Secession (1834) and in the Doleantie (1886) (In Schrotenboer, P ed. Catholicity and Secession. A Dilemma? Kampen Kok. p 76-95.)

VELEMA, W H 1957. De leer van de Heilige Geest bij Abraham Kuyper 's-Gravenhage Van Keulen

VOETIUS, G 1887 Selectarum disputationum fasciculus Fd. A Kuyper Amsterdam Wormser 
